\title{
Afatinib for the treatment of metastatic non-small cell lung cancer
}

This article was published in the following Dove Press journal:

Cancer Management and Research

19 February 2015

Number of times this article has been viewed

Monika Joshi

Syed M Rizvi

Chandra P Belani

Penn State Milton S Hershey Medical Center, Department of Medicine, Division of Hematology-Oncology, Hershey, PA, USA

Video abstract

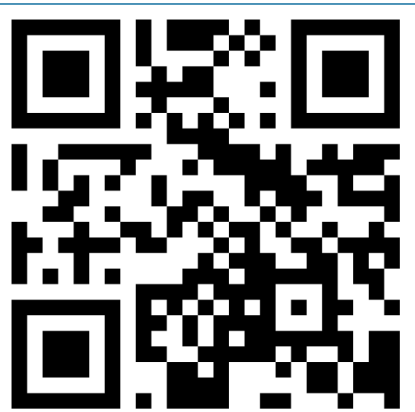

Point your SmartPhone at the code above. If you have a QR code reader the video abstract will appear. Or use: http://dvpr.es/luRSLHz
Correspondence: Monika Joshi Penn State Milton S Hershey Medical Center, Penn State College of Medicine, Department of Medicine, Division of Hematology-Oncology, Mail Code $\mathrm{CH} 46$, 500 University Drive, PO Box 850,

Hershey, PA 17033, USA

Tel +I 7175318678

Fax +I 7175315076

Email mjoshi@hmc.psu.edu
Abstract: Targeting the epidermal growth factor receptor (EGFR) in patients with non-small cell lung cancer (NSCLC) harboring sensitizing mutations in the tyrosine kinase (TKI) domain has led to a significant change in the management of this disease. The classic or sensitizing mutations are G719X mutation in exon 18, in-frame deletions or insertion of exon 19, L858R or L861Q mutation in exon 21. Approximately $90 \%$ of these mutations are exon 19 deletion or exon 21 L858R point mutation. Gefitinib and erlotinib are reversible first-generation inhibitors of mutant EGFR, and treatment with these agents in the first-line setting has demonstrated a progression-free survival of 9.5-13.7 months. However, the majority of these patients ultimately develop resistance to these drugs. Afatinib is an irreversible pan-ErbB inhibitor that was developed to circumvent the problem of resistance to first-generation TKIs. The LUX-Lung studies have evaluated the efficacy and toxicities of afatinib in treatment-naïve and refractory NSCLC patients. The promising results of some of these trials led to approval of afatinib by the US Food and Drug Administration for patients with advanced NSCLC and EGFR exon 19 deletions or exon 21 (L858R) substitution mutations. Afatinib causes toxicities similar to those of the firstgeneration EGFR TKIs, such as diarrhea, rash, acne, and stomatitis, and overall is well tolerated. This article focuses on the clinical studies of afatinib in patients with NSCLC.

Keywords: afatinib, non-small cell lung cancer, epidermal growth factor receptor, tyrosine kinase inhibitor

\section{Introduction}

Lung cancer is a leading cause of cancer-related mortality in both men and women worldwide. ${ }^{1}$ In 2014, lung cancer accounted for 224,000 new cases and 159,260 deaths in the US. ${ }^{1}$ Non-small cell lung cancer (NSCLC) accounts for $85 \%$ of all lung cases diagnosed every year, and small cell lung cancer and neuroendocrine tumors form the rest of the group. ${ }^{2}$ When detected in the early stages (stage I, II, and select stage III), the treatment goal is curative, but for stage IV NSCLC, the overall goal still remains largely palliative.

Historically, platinum-based chemotherapy doublets have been at the forefront of treatment for metastatic NSCLC. However, a better understanding of the molecular biology of NSCLC over the last decade or more has uncovered a number of potential therapeutic targets that has changed the current landscape of treatment for patients with advanced NSCLC. High-throughput tumor profiling technologies, like next-generation sequencing, have advanced our understanding of the cancer genome, therefore further unraveling the molecular basis of lung cancer progression. ${ }^{3}$ Dependence of cancer cells on pathogenic oncogenes for malignant progression has been exploited in the 
development of targeted therapies for lung cancer, ushering in an era of personalized medicine. ${ }^{4}$

Multiple driver mutations that play a major role in the development and progression of NSCLC have been identified, such as epidermal growth factor receptor (EGFR), Kristen rat sarcoma viral oncogene (KRAS), and v-Raf murine sarcoma viral oncogene (BRAF). ${ }^{2}$ Compared with smoking-related NSCLC (which has a higher incidence of KRAS, not readily targetable), NSCLC unrelated to smoking has a higher prevalence of targetable mutations. ${ }^{2}$ Driver genomic events may involve targetable kinases, including but not limited to EGFR and anaplastic lymphoma kinase $(\mathrm{ALK}){ }^{2}$ Better understanding of these driver mutations has allowed development of small-molecule tyrosine kinase inhibitors (TKIs) that are being used as therapeutic agents. ${ }^{5-8}$ Single-agent EGFR TKIs such as erlotinib, gefitinib, afatinib, and an ALK inhibitor, crizotinib, are being used as first-line therapy for patients with advanced NSCLC who have activating EGFR mutation and ALK rearrangements, respectively. These targeted therapies are producing high response rates $(60 \%-70 \%)$ and extremely impressive disease control rates (85\%-95\%), leading to US Food and Drug Administration approval of their use as first-line therapies in select patients with advanced NSCLC. This review focuses on EGFR mutations in NSCLC and, in particular, the use of afatinib, a second-generation irreversible TKI.

\section{EGFR-mutant NSCLC}

EGFR belongs to the ErbB family of transmembrane tyrosine kinase receptors (ErbB comprises ErbB1/EGFR/HER1, ErbB2/HER2/NEU, ErbB3/HER3, and ErbB4/HER4). EGFR exists as a monomer and can initiate the signaling cascade in response to epidermal growth factor ligand by itself through homodimerization or heterodimerization (by transactivation of other HER family receptors) resulting in growth and apoptosis..$^{9,10}$ EGFR exists in an equilibrium that controls its ability to transition from an inactive to an active state and vice versa. ${ }^{9,11}$ In an active state, it allows for transfer of a phosphate from adenosine triphosphate, bound to its kinase domain, to peptide substrates downstream to sustain cell growth and proliferation. ${ }^{9-11}$ It has an extracellular domain and an intracellular domain, and serves as an enticing molecule for targeted therapies. The intracellular kinase domain serves as a binding site for TKIs.

Mutations in exons 18-21 of EGFR form therapeutic targets in NSCLC. ${ }^{12-14}$ The structural changes as a result of the mutation are located within the adenosine triphosphate binding domain of the kinase. ${ }^{2}$ Mutations such as G719X mutation in exon 18, in frame deletions or insertion of exon 19, and L858R or L861Q mutation in exon 21 are considered as the classic or sensitizing EGFR mutations in NSCLC. Approximately $90 \%$ of these sensitizing mutations are exon 19 deletion or exon 21 L858R point mutation. ${ }^{15}$ These mutations lead to increased kinase activity of EGFR, leading to the hyperactive downstream pathway and resulting in increased prosurvival signals. The exon 19 deletion and exon $21 \mathrm{~L} 858 \mathrm{R}$ point mutation lead to a decreased adenosine triphosphate binding affinity in favor of a much higher affinity for small-molecule TKIs ${ }^{11}$ when compared with wild-type EGFR. The EGFR-sensitizing mutations are more prevalent in patients with adenocarcinoma histology of NSCLC, never smokers or light smokers, women, and people of East Asian descent. ${ }^{15}$ The frequency of EGFR mutation can be as high as $50 \%$ in never smokers of Asian descent. ${ }^{2}$ Exon 20 insertions (except A763_Y764 insFQEA mutation) and T790M mutation confer resistance to EGFR TKIs. ${ }^{16}$

Gefitinib and erlotinib, first-generation small-molecule EGFR TKIs, are reversible inhibitors of EGFR and were approved for clinical use prior to our understanding of the role of EGFR mutation status in NSCLC. ${ }^{17,18}$ However, the role of somatic EGFR mutations as predictive biomarkers of response and resistance to EGFR TKIs has since then been validated and is now well established. ${ }^{19}$ Clinical trials like OPTIMAL (CTONG-0802, a randomized, open-label, Phase III study of first-line erlotinib versus chemotherapy in patients with advanced EGFR mutation-positive NSCLC) ${ }^{20}$ and IPASS (Iressa Pan Asia Study) ${ }^{6}$ have shown clear improvements in response rates and progression-free survival (PFS) with erlotinib and gefitinib, respectively, in the first-line setting when compared with platinum-based chemotherapy. Despite an initial response with TKIs, the median time to disease progression is generally within 10-13 months of therapy due to development of resistance to EGFR-directed therapy. ${ }^{6,21,22}$ The most common cause of acquired resistance to EGFR TKIs is the development of a missense mutation in exon 20 of the EGFR kinase domain, T790M. ${ }^{23,24}$ Other mechanisms of resistance to EGFR TKIs include bypass of carcinogenesis via other genomic drivers (hepatocyte growth factor receptor or MET, ErbB2), epithelial to mesenchymal transition, and transformation into high-grade small cell histology. ${ }^{19,25}$ Approximately $49 \%-63 \%$ of patients with resistance to first-line EGFR TKIs will have T790M missense mutation. ${ }^{23,24}$ This confers resistance by increasing the affinity of the binding site for ATP instead of small-molecule TKIs. Clonal selection of cells harboring this mutation over time is thought to lead to refractoriness to erlotinib and gefitinib. 
Therefore, increased interest in circumventing this problem led to the development of second-generation TKIs, eg, afatinib, which irreversibly bind to the catalytic site using covalent bonds. ${ }^{26}$

\section{Afatinib}

Afatinib is a derivative of the aniline-quinazoline series of compounds and irreversibly inhibits all ErbB family receptor tyrosine kinases by covalently binding to cysteine residues within the catalytic domain, Cys773 of EGFR, Cys 805 of HER2, and Cys 803 of ErbB4. ${ }^{26,27}$ Afatinib not only blocks EGFR but also blocks the preferred dimerization of EGFR with HER2, causing an impediment of downstream signaling, which forms an important rationale for overcoming resistance after treatment with first-generation EGFR TKIs. ${ }^{19}$ In preclinical studies, afatinib was more effective in suppressing the kinase activity of wild-type and activated EGFR and HER2 mutants, including erlotinib-resistant isoforms in lung cancer cell lines with wild-type EGFR, L858R/T790M double mutation, and HER2 overexpression. ${ }^{26,28}$ The promising preclinical studies paved the way for Phase I studies which established the safe dose of afatinib to be $40-50 \mathrm{mg}$ per day orally for future clinical trials ${ }^{29,30}$ (LUX-Lung studies are listed in Table 1).

LUX-Lung 2, a Phase II study, evaluated response rates in the first-line and second-line settings in EGFR inhibitor-naïve patients with EGFR-mutant metastatic NSCLC. One hundred and twenty-nine patients were enrolled in the study and two different starting doses of afatinib was used, ie, $50 \mathrm{mg}$ per day $(n=99)$ or $40 \mathrm{mg}$ per day $(n=30) .{ }^{31}$ The results demonstrated an objective response rate (ORR) of $66 \%$ amongst the entire group, with higher response rates seen in patients with either of the two common activating EGFR mutations (exon 19 deletion or L858R) when compared with other EGFR mutations $(66 \%$ versus $39 \%) .{ }^{31}$ No significant difference in response was seen between the two doses, but afatinib-related toxicities (diarrhea and rash) were lower in the group receiving $40 \mathrm{mg}$ per day when compared with $50 \mathrm{mg}$ per day, hence $40 \mathrm{mg}$

Table I LUX-Lung clinical trials

\begin{tabular}{|c|c|c|c|c|c|c|c|}
\hline Trial & $\begin{array}{l}\text { Study phase } \\
\text { and design }\end{array}$ & $\begin{array}{l}\text { EGFR } \\
\text { mutation } \\
\text { status }\end{array}$ & $\begin{array}{l}\text { Line of } \\
\text { therapy }\end{array}$ & $\begin{array}{l}\text { Afatinib } \\
\text { (daily dose) }\end{array}$ & Control arm & $\begin{array}{l}\text { Patients } \\
\text { (n) }\end{array}$ & Primary end point \\
\hline LUX-Lung I ${ }^{36}$ & $\begin{array}{l}\text { IIB/III } \\
\text { Randomized, } \\
\text { placebo- } \\
\text { controlled }\end{array}$ & Not required & $\begin{array}{l}\text { Third or } \\
\text { fourth }\end{array}$ & $50 \mathrm{mg}$ & Placebo & 585 & $\begin{array}{l}\text { OS: I0.8 versus } \\
\text { I } 2.0 \text { months }(\mathrm{HR} \text { I.08, } \\
95 \% \mathrm{Cl} 0.86-\mathrm{I} .35 \\
P=0.74)\end{array}$ \\
\hline LUX-Lung $2^{31}$ & $\begin{array}{l}\text { II } \\
\text { Single-arm, open- } \\
\text { label }\end{array}$ & Positive & $\begin{array}{l}\text { First or } \\
\text { second }\end{array}$ & $40 \mathrm{mg}$ or $50 \mathrm{mg}$ & No & 129 & $\begin{array}{l}\text { ORR: } 61 \% \text { (two CR, } \\
77 \text { PR) }\end{array}$ \\
\hline LUX-Lung $3^{8}$ & $\begin{array}{l}\text { III } \\
\text { Randomized (2:I), } \\
\text { open-label }\end{array}$ & Positive & First & $40 \mathrm{mg}$ & $\begin{array}{l}\text { Pemetrexed + } \\
\text { cisplatin }\end{array}$ & 345 & $\begin{array}{l}\text { PFS: I I.I versus } \\
6.9 \text { months (HR 0.58; } \\
95 \% \mathrm{Cl} \mathrm{0.43-0.78;} \\
P=0.00 \mathrm{I})\end{array}$ \\
\hline LUX-Lung $4^{37}$ & $\begin{array}{l}\text { I/II } \\
\text { Open-label }\end{array}$ & Not required & $\begin{array}{l}\text { Second or } \\
\text { beyond }\end{array}$ & $50 \mathrm{mg}$ & & 90 & $\begin{array}{l}\text { Part I: safety } \\
\text { Part 2: ORR, } 8.2 \% \\
(95 \% \mathrm{Cl} 2.7-18.1)\end{array}$ \\
\hline LUX-Lung $5^{44}$ & $\begin{array}{l}\text { III } \\
\text { Randomized, } \\
\text { open-label }\end{array}$ & Not required & $\begin{array}{l}\text { Third or } \\
\text { fourth }\end{array}$ & $\begin{array}{l}\text { Part A: } 40 \mathrm{mg} \\
\text { Part B: } 40 \mathrm{mg}+ \\
\text { paclitaxel }\end{array}$ & $\begin{array}{l}\text { Part A: none } \\
\text { Part B: investigator's } \\
\text { choice }\end{array}$ & $\mathrm{I}, 154$ & $\begin{array}{l}\text { PFS: part } B, 5.6 \text { versus } \\
2.8 \text { months, (HR 0.60, } \\
95 \% \mathrm{Cl} 0.43-0.85 ; \\
P=0.003)\end{array}$ \\
\hline LUX-Lung $6^{33}$ & $\begin{array}{l}\text { III } \\
\text { Randomized, } \\
\text { open-label }\end{array}$ & Positive & First & $40 \mathrm{mg}$ & $\begin{array}{l}\text { Gemcitabine + } \\
\text { cisplatin }\end{array}$ & 364 & $\begin{array}{l}\text { PFS: I I.0 versus } \\
5.6 \text { months (HR } 0.28 \text {, } \\
95 \% \mathrm{Cl} 0.20-0.39 \\
P<0.000 \mathrm{I})\end{array}$ \\
\hline LUX-Lung $7^{26}$ & $\begin{array}{l}\text { Ilb } \\
\text { Randomized, } \\
\text { open-label }\end{array}$ & Positive & First & $40 \mathrm{mg}$ & Gefitinib & 264 & PFS: study is ongoing \\
\hline LUX-Lung $8^{35}$ & $\begin{array}{l}\text { III } \\
\text { Randomized, } \\
\text { open-label }\end{array}$ & Not required & Second & $40 \mathrm{mg}$ & Erlotinib & 800 & $\begin{array}{l}\text { PFS: } 2.4 \text { versus } 1.9 \\
\text { months }(\mathrm{HR} 0.82,95 \% \mathrm{Cl} \\
0.68-1.0 ; P=0.043)\end{array}$ \\
\hline
\end{tabular}

Abbreviations: EGFR, epithelial growth factor receptor; ORR, objective response rate; OS, overall survival; PFS, progression-free survival; PD, progressive disease; $\mathrm{PR}$, partial response; CR, complete response; $\mathrm{Cl}$, confidence interval; $\mathrm{HR}$, hazard ratio. 
per day dosing was selected for future Phase III studies. ${ }^{19}$ The promising efficacy of afatinib in this Phase II study formed the rationale for its further development.

\section{Afatinib in TKI-naïve patients}

Afatinib was compared with standard platinum-based doublet chemotherapy in two large, randomized Phase III studies, ie, LUX-Lung 3 and LUX-Lung 6, in patients with EGFRmutant advanced NSCLC. Cisplatin/pemetrexed was used in LUX-Lung 3 as the control arm whereas gemcitabine/ cisplatin was used as the control arm in the LUX-Lung 6 study. ${ }^{8}$ LUX-Lung 6 was conducted in East Asia and LUXLung 3 recruited patients globally. PFS was 11.1 months versus 6.9 months (hazard ratio [HR] 0.58, 95\% confidence interval [CI] $0.43-0.78, P=0.001$ ) in LUX-Lung 3 when afatinib was compared with the platinum doublet in all of the EGFR-mutant disease population. This difference in PFS was greater (13.6 months versus 6.9 months; HR 0.47, 95\% CI $0.34-0.65, P=0.001)$ in patients whose tumors had exon 19 deletion or L858R EGFR mutations. ${ }^{8}$ LUX-Lung 6 reported a PFS of 11.0 months with afatinib versus 5.6 months with the platinum doublet-containing arm (HR $0.28, P<0.0001) .{ }^{32,33}$ Both trials failed to show an overall survival (OS) benefit; however, a pooled analysis of these two studies, presented at the American Society of Clinical Oncology meeting in Chicago in 2014, ${ }^{34}$ showed a survival advantage of 3 months for patients treated with afatinib compared with the chemotherapy arm. In total, 631 of 709 patients enrolled in the two trials with common EGFR mutations (exon 19 deletions or L858R) were studied in the pooled analysis. OS in the afatinib arm was 27.3 months as opposed to 24.3 months in the chemotherapy arm (HR $0.81, P=0.037)$ and this was supposedly statistically significant. ${ }^{19,34}$ However, the analysis of survival is flawed because of the "pooling effect" from the two studies. Also, interestingly, in both trials, the median OS was higher amongst patients with exon 19 deletion.

Afatinib was compared with erlotinib in LUX-Lung 8, a randomized Phase III study in TKI-naïve patients with relapsed/refractory squamous cell lung cancer (total patients at the time of analysis, $n=669$; afatinib $n=335$, erlotinib $\mathrm{n}=334$ ) who had failed a platinum doublet. ${ }^{35}$ Although the trial was powered for both PFS and OS, PFS was the primary end point. Median PFS was significantly higher for afatinib than for erlotinib, both by independent radiological review (2.4 versus 1.9 months; $P=0.0427$ ) and by investigator review (2.7 versus 1.9 months; $P=0.0053$ ). ${ }^{35}$ The ORR was not different in the two groups ( $4.8 \%$ versus $3.0 \% ; P=0.233)$, but the disease control rate was significantly higher with afatinib than with erlotinib ( $45.7 \%$ versus $36.8 \% ; P=0.020$ ). However, a higher incidence of grade 3 drug-related toxicities, ie, diarrhea (9.7\% versus $2.4 \%)$ and stomatitis $(3.3 \%$ versus $0.0 \%$ ), was reported with afatinib despite grade 3 rash/acne being greater in the erlotinib arm $(5.5 \%$ versus $9.0 \%$ ). The OS data from this trial is eagerly awaited.

LUX-Lung 7, a randomized Phase IIb study comparing afatinib with gefitinib in the first-line setting for the treatment of EGFR mutant adenocarcinoma of the lung, is currently underway (NCT01466660). The study has completed accrual and is awaiting analysis.

\section{Afatinib in TKI-exposed patients}

LUX-Lung 1 was a Phase IIb/III study that looked at the benefit of afatinib and best supportive care in comparison with placebo and best supportive care, as a third-line or fourth-line therapy in patients who had received a platinum doublet and a first-generation TKI for at least 3 months. ${ }^{36}$ A total of 697 patients were enrolled and 585 of them received afatinib. This study failed to demonstrate an OS benefit as its primary end point due to a higher median OS seen in the placebo arm. The subsequent cancer treatment difference (257 [68\%] patients in the afatinib group and 153 [79\%] patients in the placebo group) may be attributable to the lack of a significant difference in OS between the two groups. However, in a post hoc analysis, an improved OS of 5.8 months was reported with afatinib in comparison with 4.6 months for placebo when the placebo group was controlled for no subsequent antitumor therapies (HR 0.65). ${ }^{19}$ Although this study did not mandate the presence of EGFR mutations, 141 patient tissue samples were analyzed, and of these, 96 (68\%) showed the presence of EGFR-sensitizing mutations. Median PFS was longer in the afatinib group than in the placebo group (3.3 months versus 1.1 months; HR $0.38,95 \%$ CI $0.31-0.48, P<0.0001) .{ }^{36}$

Afatinib was also studied in Japanese patients who had progressed on erlotinib and/or gefitinib in LUX-Lung 4, a Phase II single-arm study. ${ }^{19,37}$ Sixty-two patients were enrolled in the study and 45 (72.6\%) were EGFR mutation-positive in their primary tumor according to local and/or central laboratory analyses. Fifty-one (82.3\%) of these had acquired resistance to first-generation EGFR TKIs. The median PFS was 4.4 months (95\% CI 2.8-4.6) and the median OS was 19.0 months (95\% CI 14.9 to not achieved). Two patients meeting the resistance criteria with a secondary T790M mutation (L858R + T790M and deletion exon $19+\mathrm{T} 790 \mathrm{M}$ ) had stable disease for 9 months and one month, respectively. ${ }^{19,37}$ Diarrhea and rash were the predominant adverse events with afatinib. This trial 
showed a modest efficacy of afatinib in a heavily pretreated lung cancer population.

\section{Afatinib in combination with chemotherapy}

First-generation TKIs have been used in combination with chemotherapy in the INTACT (Iressa NSCLC Trial Assessing Combination Treatment)-1, INTACT-2, TRIBUTE (Tarceva responses in conjunction with paclitaxel and carboplatin), and TALENT (Tarceva Lung Cancer Investigation) trials. ${ }^{38-41}$ None of these trials showed any benefit in PFS or OS. However, Lee et al recently reported the results of a metaanalysis of 23 trials (13 front-line, seven second-line, three maintenance; $n=14,570$ ) that evaluated EGFR inhibitors as monotherapy or in combination with chemotherapy. ${ }^{42}$ In the four abovementioned trials, ${ }^{38-41}$ which initially were negative, a PFS benefit was seen in the EGFR mutation-positive NSCLC subgroup (HR 0.54). ${ }^{42}$ Similarly, for this EGFR mutation-positive group, improvements in PFS and OS were also reported for adding intercalated erlotinib to a platinumbased combination regimen in the FAST-ACT (First-Line Asian Sequential Tarceva and Chemotherapy Trial) $1^{6}$ and FAST-ACT $2^{43}$ trials.

Similarly, a randomized Phase III trial, LUX-Lung 5, looked at the benefit of afatinib in combination with chemotherapy in patients who progressed on monotherapy with afatinib and had previously been treated with chemotherapy and/or a first-generation TKI. ${ }^{19,44}$ Patients initially received $50 \mathrm{mg}$ of afatinib once a day and, on disease progression at 12 weeks or beyond, were randomized to afatinib/paclitaxel (40 $\mathrm{mg}$ daily $/ 80 \mathrm{mg} / \mathrm{m}^{2}$, respectively) or the investigator's choice of chemotherapy. ${ }^{19,44}$ Combination treatment resulted in increased PFS when compared with chemotherapy alone ( 5.6 versus 2.8 months; HR $0.60,95 \%$ CI $0.43-0.85, P=0.003)$. The ORR was also significantly higher in the combination arm $(32.1 \%$ versus $13.2 \%, P=0.005)$. OS was similar in both arms $(12.2$ versus 12.2 months; HR 1.00, 95\% CI 0.70, 1.43, $P=0.994$ ), although a higher incidence of toxicities like diarrhea, alopecia, and asthenia were observed in the combination therapy arm. This study showed that tumors progressing on TKIs continue to depend on signaling through the receptors of the ErbB family and can benefit from continuous ErbB family blockade, although more studies are needed to confirm this concept.

\section{Afatinib in combination with cetuximab}

Both first-generation and second-generation TKIs fail to show a durable or curative response, due to the emergence of a secondary mutation in EGFR, ie, the EGFR T790M mutation. It is thought that EGFR T790M mutation allows cancer cells to maintain oncogenic signaling, causing failure to maintain a sustained response to EGFR TKIs. Studies using EGFR-mutant NSCLC xenograft models showed a promising synergistic effect of combining cetuximab, a monoclonal antibody that binds competitively and with high affinity to the extracellular domain of the EGFR receptor, with erlotinib. ${ }^{45}$ However, a Phase I/II study that used this rationale for combining erlotinib plus cetuximab in advanced NSCLC patients who had failed erlotinib therapy was negative, in that none of the patients in that study had a radiographic response. ${ }^{46}$ However, a majority of the patients (11 of 13) were able to achieve stable disease. ${ }^{26}$ In a preclinical study, a complete response was observed in an EGFR T790M transgenic murine mouse model of NSCLC when afatinib was used in combination with cetuximab. ${ }^{26}$ Using this as a rationale, a Phase Ib/II study of the combination of afatinib and cetuximab was conducted in patients with NSCLC who had acquired resistance to erlotinib or gefitinib. ${ }^{47}$ The patients in the Phase I part of the trial received afatinib $40 \mathrm{mg} /$ day along with escalating doses of cetuximab $\left(250 \mathrm{mg} / \mathrm{m}^{2}\right.$ to $500 \mathrm{mg} / \mathrm{m}^{2}$ every 2 weeks); no dose-limiting toxicities were seen, so the Phase II dose for cetuximab was $500 \mathrm{mg} / \mathrm{m}^{2}$ every 2 weeks. ${ }^{48}$ Amongst 96 evaluable patients in the expansion cohort, an ORR of $30 \%$ was seen, with $75 \%$ of patients showing a partial response or stable disease. Interestingly, responses occurred in patients with confirmed T790M mutation as well as in those who did not have a T790M secondary mutation (32\% partial response and 49\% stable disease in T790M-positive patients versus $28 \%$ partial response and $36 \%$ stable disease in T790M-negative patients). Rash (97\%) and diarrhea (71\%) were the most common toxicities associated with the combination therapy. These results are certainly encouraging, but further clinical studies are needed to confirm these results. Prophylactic treatment of the toxicities and dose adjustments would play an integral role when treating patients with this combination strategy.

\section{Toxicities}

Afatinib has toxicities similar to those of the first generation EGFR TKIs, such as, diarrhea, rash or acne, stomatitis, paronychia, decreased appetite and nausea. Please refer to Table 2 for common toxicities reported in the LUX-Lung trials. Overall, diarrhea was the most common side effect in the LUX-Lung trials, and grade 3 diarrhea occurred in $17 \%-22 \%$ of the patients. ${ }^{26}$ This incidence of grade 3 diarrhea is higher than that reported with erlotinib or gefitinib 
Table 2 Common toxicities reported in the LUX-Lung trials

\begin{tabular}{|c|c|}
\hline Trial & Incidence of toxicity associated with afatinib \\
\hline LUX-Lung| ${ }^{36}$ & $\begin{array}{l}\text { - Diarrhea: } 87 \% \text { ( } 17 \% \text { were grade } 3) \\
\text { - Acneiform rash: } 78 \% \text { ( } 14 \% \text { were grade } 3) \\
\text { - Possible treatment-related death: } 2 \text { patients }\end{array}$ \\
\hline LUX-Lung $2^{31}$ & $\begin{array}{l}\text { - Diarrhea grade } 3: 22 \% \text { in } 50 \mathrm{mg} / \text { day group and } 7 \% \text { in } \\
40 \mathrm{mg} / \text { day group } \\
\text { - Rash/acne grade } 3: 28 \% \text { in } 50 \mathrm{mg} / \text { day group and } 7 \% \text { in } \\
40 \mathrm{mg} / \text { day group }\end{array}$ \\
\hline LUX-Lung $3^{8}$ & $\begin{array}{l}\text { - Diarrhea: } 95.2 \% \text { of patients ( } 14.4 \% \text { had grade } 3 \text { ) } \\
\text { - Rash: } 89.1 \% \text { of patients (16.2\% had grade } 3 \text { ) } \\
\text { - Mucositis: } 72.1 \% \text { ( } 8.7 \% \text { had grade } 3 \text { and } 0.4 \% \text { had } \\
\text { grade } 4 \text { ) } \\
\text { - Paronychia: } 56.8 \% \text { ( } 11.4 \% \text { had grade } 3 \text { ) } \\
\text { - Deaths: } 4 \text { patients }\end{array}$ \\
\hline LUX-Lung $4^{37}$ & $\begin{array}{l}\text { - Diarrhea: } 100 \% \\
\text { - Rash/acne: } 91.9 \% \\
\text { - Discontinuation of afatinib due to side effects: } 29 \%\end{array}$ \\
\hline LUX-Lung $5^{44}$ & $\begin{array}{l}\text { - Diarrhea: } 53.8 \% \\
\text { - Alopecia: } 32.6 \% \\
\text { - Asthenia: } 27.3 \%\end{array}$ \\
\hline LUX-Lung $6^{33}$ & $\begin{array}{l}\text { - Rash/acne: } 14.6 \% \\
\text { - Diarrhea: } 5.4 \% \\
\text { - Stomatitis/mucositis: } 5.4 \% \\
\text { - Treatment-related serious adverse events: } 6.3 \%\end{array}$ \\
\hline LUX-Lung 7 & - Ongoing ClinicalTrials.gov identifier: NCTOI 466660 \\
\hline LUX-Lung $8^{31}$ & $\begin{array}{l}\text { - Diarrhea: } 9.7 \% \text { ( } \geq \text { grade } 3 \text { ) } \\
\text { - Rash/acne: } 5.5 \% \text { (grade 3) } \\
\text { - Stomatitis: } 3.3 \% \text { (grade 3) }\end{array}$ \\
\hline
\end{tabular}

in the LUX-Lung 3 and LUX-Lung 4 trials. ${ }^{8,37}$ However, the rate of grade 3 toxicities dropped in the LUX-Lung 6 trial; this could have been because the treating physicians became quite adept at managing the side effects of afatinib and what was earlier perceived as higher grade toxicity was now thought to be of lower severity. ${ }^{26,33}$ Diarrhea, paronychia, and stomatitis were worse with afatinib than with erlotinib, whereas no clear difference was observed in the frequency or severity of skin rash. ${ }^{49}$

Treatment of afatinib-related toxicities should be addressed as soon as possible after the onset of symptoms. Patient education prior to starting therapy is crucial in the management of adverse events. Education should be given to the patient about the specific side effects associated with afatinib, including its frequency and severity and the overall significance of delaying therapy. Skin rash, one of the common side effects of afatinib, is usually localized to the face and trunk. ${ }^{50}$ The rash can improve or resolve with continued use of afatinib, but sometimes dose reduction or discontinuation of therapy is required..$^{50}$ Prior to starting therapy, patients should be educated to avoid exposure to direct sunlight. Liberal use of sunscreen lotion to exposed areas and protective clothing should be advised to minimize exposure to sun.
If skin rash occurs, treatment should be initiated without delay ${ }^{50}$ For mild skin rash (grade 1-2), afatinib can be continued at the same dose with addition of topical antibiotic and steroid cream. ${ }^{50}$ Addition of an oral antibiotic for 6 weeks can be considered as an alternative in selected patients with grade 2 rash. However, if patients develop grade 3 rash or worse, afatinib should be discontinued and a course of oral antibiotic for 6 weeks or a referral to dermatologist should be made..$^{50}$ Once symptoms improve to baseline or to a grade 1 level, afatinib can be restarted at a lower dose (reduce dose by $10 \mathrm{mg}$ /day). Diarrhea usually occurs within a week of treatment with afatinib, and early management is essential to prevent discontinuation of therapy. ${ }^{51}$ Patients should be advised to use antidiarrheal agents, such as loperamide (4 $\mathrm{mg}$ followed by $2 \mathrm{mg}$ after each loose stool, with no more than $16 \mathrm{mg} /$ day), immediately at the onset of diarrhea. ${ }^{51}$ In addition, advice should be provided to increase the oral fluid intake, along with dietary recommendations to prevent electrolyte imbalance. If a patient develops more severe diarrhea ( $\geq$ grade 3 ), hospitalization for supportive care is recommended to minimize complications, and afatinib should be discontinued and restarted at a lower dose once symptoms resolve. ${ }^{51}$ Stool cultures and prophylactic antibiotic therapy should be considered if there is any suspicion of an infectious etiology for diarrhea.

However, it is important to point out that, in spite of these toxicities, only $8 \%$ of patients discontinued afatinib in LUX-Lung 1 and 3 trials while only $5.9 \%$ of patients discontinued therapy in LUX-Lung 6. ${ }^{8,33,36}$ In addition, patients also reported improvement in cough, dyspnea, and pain, as well as improvement in overall quality of life with afatinib. In summary, afatinib is a potent TKI but has more side effects when compared with first-generation TKIs.

\section{Conclusion}

Currently, afatinib is approved in the USA at a dose of $40 \mathrm{mg}$ once daily for the treatment of metastatic NSCLC with EGFR exon 19 deletions or exon 21 (L858R) substitution mutations. Afatinib has improved the PFS and OS in comparison with chemotherapy when used in the first-line setting. Maximal survival benefit is seen in patients with advanced NSCLC and the del-19 mutant. However, like any other TKI, afatinib also comes with the challenge of tumors developing resistance. Gene dosage of EGFR T790M allele in in-vitro models has been thought to be one of the factors that abrogates the efficacy of afatinib. ${ }^{52}$ Perhaps, at the current approved dosage, inhibition of clones harboring T790Mmutant cells is not sufficient. In addition, factors causing 
development of resistance to first-generation TKIs, transformation into high-grade small cell histology, bypassing via other genomic drivers (hepatocyte growth factor receptor or MET, ErbB2) and epithelial to mesenchymal transition, may be playing a role as well in the development of resistance to afatinib. ${ }^{26}$ Since EGFR signaling is not interrupted after development of resistance to TKIs, dual inhibition with cetuximab and first/second-generation EGFR TKIs has been looked at, and the data from the early clinical trial using a combination of cetuximab and afatinib appears promising. ${ }^{26}$ However, the side effect profile of this combination therapy certainly raises questions regarding tolerability, and optimal management of toxicity would be crucial for further development of this therapeutic strategy. Another strategy would be to test the afatinib and cetuximab combination upfront in patients with EGFR mutation-positive advanced NSCLC. We still need a predictive biomarker for this combination therapy, and that would help select the correct patient population. Newer-generation EGFR TKIs with more specific activity at T790M mutation, such as C0-1686 and AZD9291, seem to have a better toxicity profile in early clinical trials as monotherapy, and the results are very encouraging in patients with advanced NSCLC who develop resistance to EGFR TKI with secondary T790M mutation. Ongoing robust research from the laboratory to the clinic and vice versa in the field of EGFR-directed therapy for NSCLC will hopefully provide a better tomorrow for our patients.

\section{Disclosure}

The authors report no conflicts of interest in this work.

\section{References}

1. Siegel R, Ma J, Zou Z, Jemal A. Cancer statistics, 2014. CA Cancer J Clin. 2014;64(1):9-29.

2. Jorge SE, Kobayashi SS, Costa DB. Epidermal growth factor receptor (EGFR) mutations in lung cancer: preclinical and clinical data. Braz $J$ Med Biol Res. 2014;47(11):929-939.

3. Meyerson M, Gabriel S, Getz G. Advances in understanding cancer genomes through second-generation sequencing. Nat Rev Genet. 2010; 11(10):685-696.

4. Yap TA, Sandhu SK, Workman P, de Bono JS. Envisioning the future of early anticancer drug development. Nat Rev Cancer. 2010;10(7): 514-523.

5. Kwak EL, Bang YJ, Camidge DR, et al. Anaplastic lymphoma kinase inhibition in non-small-cell lung cancer. $N$ Engl J Med. 2010;363(18): 1693-1703.

6. Mok TS, Wu YL, Thongprasert S, et al. Gefitinib or carboplatinpaclitaxel in pulmonary adenocarcinoma. $N$ Engl J Med. 2009;361(10): 947-957.

7. Rosell R, Carcereny E, Gervais R, et al. Erlotinib versus standard chemotherapy as first-line treatment for European patients with advanced EGFR mutation-positive non-small-cell lung cancer (EURTAC): a multicentre, open-label, randomised phase 3 trial. Lancet Oncol. 2012;13(3):239-246.
8. Sequist LV, Yang JC, Yamamoto N, et al. Phase III study of afatinib or cisplatin plus pemetrexed in patients with metastatic lung adenocarcinoma with EGFR mutations. J Clin Oncol. 2013;31(27):3327-3334.

9. Kumar A, Petri ET, Halmos B, Boggon TJ. Structure and clinical relevance of the epidermal growth factor receptor in human cancer. J Clin Oncol. 2008;26(10):1742-1751.

10. Sharma SV, Bell DW, Settleman J, Haber DA. Epidermal growth factor receptor mutations in lung cancer. Nat Rev Cancer. 2007;7(3): 169-181.

11. Eck MJ, Yun CH. Structural and mechanistic underpinnings of the differential drug sensitivity of EGFR mutations in non-small cell lung cancer. Biochim Biophys Acta. 2010;1804(3):559-566.

12. Lynch TJ, Bell DW, Sordella R, et al. Activating mutations in the epidermal growth factor receptor underlying responsiveness of non-small-cell lung cancer to gefitinib. $N$ Engl J Med. 2004;350(21):2129-2139.

13. Paez JG, Janne PA, Lee JC, et al. EGFR mutations in lung cancer: correlation with clinical response to gefitinib therapy. Science. 2004; 304(5676): 1497-1500.

14. Pao W, Miller V, Zakowski M, et al. EGF receptor gene mutations are common in lung cancers from "never smokers" and are associated with sensitivity of tumors to gefitinib and erlotinib. Proc Natl Acad Sci USA. 2004;101(36):13306-13311.

15. Shigematsu H, Lin L, Takahashi T, et al. Clinical and biological features associated with epidermal growth factor receptor gene mutations in lung cancers. J Natl Cancer Inst. 2005;97(5):339-346.

16. Yasuda H, Park E, Yun CH, et al. Structural, biochemical, and clinical characterization of epidermal growth factor receptor (EGFR) exon 20 insertion mutations in lung cancer. Sci Transl Med. 2013; 5(216):216ra177.

17. Shepherd FA, Rodrigues Pereira J, Ciuleanu T, et al. Erlotinib in previously treated non-small-cell lung cancer. $N$ Engl J Med. 2005;353(2): 123-132.

18. Thatcher N, Chang A, Parikh P, et al. Gefitinib plus best supportive care in previously treated patients with refractory advanced nonsmall-cell lung cancer: results from a randomised, placebo-controlled, multicentre study (Iressa Survival Evaluation in Lung Cancer). Lancet. 2005;366(9496):1527-1537.

19. Yap TA, Popat S. Toward precision medicine with next-generation EGFR inhibitors in non-small-cell lung cancer. Pharmgenomics Pers Med. 2014;7:285-295.

20. Zhou C, Wu YL, Chen G, et al. Erlotinib versus chemotherapy as first-line treatment for patients with advanced EGFR mutation-positive non-smallcell lung cancer (OPTIMAL, CTONG-0802): a multicentre, open-label, randomised, phase 3 study. Lancet Oncol. 2011;12(8):735-742.

21. Mitsudomi T, Morita S, Yatabe Y, et al. Gefitinib versus cisplatin plus docetaxel in patients with non-small-cell lung cancer harbouring mutations of the epidermal growth factor receptor (WJTOG3405): an open label, randomised phase 3 trial. Lancet Oncol. 2010;11(2):121-128.

22. Maemondo M, Inoue A, Kobayashi K, et al. Gefitinib or chemotherapy for non-small-cell lung cancer with mutated EGFR. $N$ Engl $J$ Med. 2010;362(25):2380-2388.

23. Arcila ME, Oxnard GR, Nafa K, et al. Rebiopsy of lung cancer patients with acquired resistance to EGFR inhibitors and enhanced detection of the T790M mutation using a locked nucleic acid-based assay. Clin Cancer Res. 2011;17(5):1169-1180.

24. Yu HA, Arcila ME, Rekhtman N, et al. Analysis of tumor specimens at the time of acquired resistance to EGFR-TKI therapy in 155 patients with EGFR-mutant lung cancers. Clin Cancer Res. 2013;19(8): 2240-2247.

25. Sequist LV, Waltman BA, Dias-Santagata D, et al. Genotypic and histological evolution of lung cancers acquiring resistance to EGFR inhibitors. Sci Transl Med. 2011;3(75):75ra26.

26. Chen X, Zhu Q, Zhu L, et al. Clinical perspective of afatinib in nonsmall cell lung cancer. Lung Cancer. 2013;81(2):155-161.

27. Solca F, Dahl G, Zoephel A, et al. Target binding properties and cellular activity of afatinib (BIBW 2992), an irreversible ErbB family blocker. J Pharmacol Exp Ther. 2012;343(2):342-350. 
28. Li D, Ambrogio L, Shimamura T, et al. BIBW2992, an irreversible EGFR/HER2 inhibitor highly effective in preclinical lung cancer models. Oncogene. 2008;27(34):4702-4711.

29. Murakami H, Tamura T, Takahashi T, et al. Phase I study of continuous afatinib (BIBW 2992) in patients with advanced non-small cell lung cancer after prior chemotherapy/erlotinib/gefitinib (LUX-Lung 4). Cancer Chemother Pharmacol. 2012;69(4):891-899.

30. Yap TA, Vidal L, Adam J, et al. Phase I trial of the irreversible EGFR and HER2 kinase inhibitor BIBW 2992 in patients with advanced solid tumors. J Clin Oncol. 2010;28(25):3965-3972.

31. Yang JC, Shih JY, Su WC, et al. Afatinib for patients with lung adenocarcinoma and epidermal growth factor receptor mutations (LUXLung 2): a phase 2 trial. Lancet Oncol. 2012;13(5):539-548.

32. Wu YL, Zhou C, Hu C-P, et al. LUX-Lung 6: A randomized, openlabel, phase III study of afatinib (A) versus gemcitabine/cisplatin (GC) as first-line treatment for Asian patients (pts) with EGFR mutationpositive (EGFR M+) advanced adenocarcinoma of the lung. J Clin Oncol. 2013;31 Suppl:Abstr 8016.

33. Wu YL, Zhou C, Hu CP, et al. Afatinib versus cisplatin plus gemcitabine for first-line treatment of Asian patients with advanced non-small-cell lung cancer harbouring EGFR mutations (LUX-Lung 6): an open-label, randomised phase 3 trial. Lancet Oncol. 2014;15(2):213-222.

34. Melosky B. Review of EGFR TKIs in metastatic NSCLC, including ongoing trials. Front Oncol. 2014;4:244.

35. Goss G, Felip E, Cobo M, et al. 1222O - A randomized, open-label, phase III trial of afatinib (A) vs erlotinib (E) as second-line treatment of patients (pts) with advanced squamous cell carcinoma (SCC) of the lung following first line therapy. Ann Oncol. 2014;25 Suppl 4: iv426-iv470.

36. Miller VA, Hirsh V, Cadranel J, et al. Afatinib versus placebo for patients with advanced, metastatic non-small-cell lung cancer after failure of erlotinib, gefitinib, or both, and one or two lines of chemotherapy (LUX-Lung 1): a phase 2b/3 randomised trial. Lancet Oncol. 2012;13(5):528-538.

37. Katakami N, Atagi S, Goto K, et al. LUX-Lung 4: a phase II trial of afatinib in patients with advanced non-small-cell lung cancer who progressed during prior treatment with erlotinib, gefitinib, or both. J Clin Oncol. 2013;31(27):3335-3341.

38. Giaccone G, Herbst RS, Manegold C, et al. Gefitinib in combination with gemcitabine and cisplatin in advanced non-small-cell lung cancer: a phase III trial - INTACT 1. J Clin Oncol. 2004;22(5):777-784.

39. Herbst RS, Giaccone G, Schiller JH, et al. Gefitinib in combination with paclitaxel and carboplatin in advanced non-small-cell lung cancer: a phase III trial - INTACT 2. J Clin Oncol. 2004;22(5):785-794.

40. Herbst RS, Prager D, Hermann R, et al. TRIBUTE: a phase III trial of erlotinib hydrochloride (OSI-774) combined with carboplatin and paclitaxel chemotherapy in advanced non-small-cell lung cancer. J Clin Oncol. 2005;23(25):5892-5899.
41. Gatzemeier U, Pluzanska A, Szczesna A, et al. Phase III study of erlotinib in combination with cisplatin and gemcitabine in advanced non-small-cell lung cancer: the Tarceva Lung Cancer Investigation Trial. J Clin Oncol. 2007;25(12):1545-1552.

42. Lee CK, Brown C, Gralla RJ, et al. Impact of EGFR inhibitor in non-small cell lung cancer on progression-free and overall survival: a meta-analysis. J Natl Cancer Inst. 2013;105(9):595-605.

43. Wu YL, Lee JS, Thongprasert S, et al. Intercalated combination of chemotherapy and erlotinib for patients with advanced stage non-small-cell lung cancer (FASTACT-2): a randomised, double-blind trial. Lancet Oncol. 2013;14(8):777-786.

44. Schuler MH, Yang C-H, Park K, et al. Continuation of afatinib beyond progression: results of a randomized, open-label, phase III trial of afatinib plus paclitaxel (P) versus investigator's choice chemotherapy (CT) in patients (pts) with metastatic non-small cell lung cancer (NSCLC) progressed on erlotinib/gefitinib (E/G) and afatinib - LUX-Lung 5 (LL5). J Clin Oncol. 2014;32:(5 Suppl):Abstr 8019.

45. Huang S, Armstrong EA, Benavente S, Chinnaiyan P, Harari PM. Dual-agent molecular targeting of the epidermal growth factor receptor (EGFR): combining anti-EGFR antibody with tyrosine kinase inhibitor. Cancer Res. 2004;64(15):5355-5362.

46. Janjigian YY, Azzoli CG, Krug LM, et al. Phase I/II trial of cetuximab and erlotinib in patients with lung adenocarcinoma and acquired resistance to erlotinib. Clin Cancer Res. 2011;17(8):2521-2527.

47. Janjigian YY, Smit EF, Horn L, et al. Activity of afatinib/cetuximab in patients (pts) with EGFR mutant non-small cell lung cancer (NSCLC) and acquired resistance (AR) to EGFR inhibitors. Ann Oncol. 2012; 23 Suppl 9:Abstr 12270.

48. Janjigian YY, Groen HJ, Horn L, et al. Activity and tolerability of afatinib (BIBW 2992) and cetuximab in NSCLC patients with acquired resistance to erlotinib or gefitinib. J Clin Oncol. 2011;29 Suppl: Abstr 7525.

49. D'Arcangelo M, Hirsch FR. Clinical and comparative utility of afatinib in non-small cell lung cancer. Biologics. 2014;8:183-192.

50. Lacouture ME, Schadendorf D, Chu CY, et al. Dermatologic adverse events associated with afatinib: an oral ErbB family blocker. Expert Rev Anticancer Ther. 2013;13(6):721-728.

51. Yang JC, Reguart N, Barinoff J, et al. Diarrhea associated with afatinib: an oral ErbB family blocker. Expert Rev Anticancer Ther. 2013;13(6):729-736.

52. Kim Y, Ko J, Cui Z, et al. The EGFR T790M mutation in acquired resistance to an irreversible second-generation EGFR inhibitor. $\mathrm{Mol}$ Cancer Ther. 2012;11(3):784-791.
Cancer Management and Research

\section{Publish your work in this journal}

Cancer Management and Research is an international, peer-reviewed open access journal focusing on cancer research and the optimal use of preventative and integrated treatment interventions to achieve improved outcomes, enhanced survival and quality of life for the cancer patient. The journal welcomes original research, clinical \& epidemiological

\section{Dovepress}

studies, reviews \& evaluations, guidelines, expert opinion \& commentary, case reports \& extended reports. The manuscript management system is completely online and includes a very quick and fair peerreview system, which is all easy to use. Visit http://www.dovepress.com/ testimonials.php to read real quotes from published authors. 